\title{
下村喜三郎と郊外住宅地開発 \\ KISABUROU SHIMOMURA AND SUBURBAN HOUSING DEVELOPMENT
}

\author{
和田康由*，寺内 信** \\ Yasuyoshi WADA and Makoto TERAUCHI
}

\begin{abstract}
This study will show how suburban housing was developed before the war, through Kisaburou Shimomura's achievements. When he worked for Kansai Tochi Co. Ltd., He visited countries in Europe to see the "garden city" movement. He designed Ohmino Den-en Toshi. He tried to create a "garden city" worthy of the name by intoroducing the concept of radiating roads and setting limits on the use of land. Moreover, by publishing pamphlets and the KANSAI TOCHI JIHO, . he was eager to educate others on European land use and British "garden city" idea at the beginning of the twentieth century. He was transferred to Hanshin Kyuko Dentetsu Co. Ltd., took part in housing management for office workers at Tsukaguchi Estate, and he opened a drafting office. He was active as an architect and housing designer.
\end{abstract}

\footnotetext{
Keywords : Kisaburou Shimomura, suburban housing, Kansai Tochi Co. Ltd., Ohmino Den-en Toshi, Hanshin Kyuko Dentetsu Co. Ltd.

下村喜三郎，郊外住宅地，関西土地侏，大美野田園都市，阪神急行電鉄侏)
}

\section{1.はじめに}

明治末から大正末にかけて土地会社が数多く設立され，経営地の 对象を郊外に向けていた。大美野田園都市を開発した関西土地株式 会社もそうした部類に属している。同社が開発した大美野田園都市 については, 従来, その背景や計画者等の詳細が十分論じられてい たとは言えない。本論文1では, 大美野田園都市の主たる計画者下村 喜三郎を取り上げ，彼の履歴，思想・デザイン上での影響関係を探 ることから, 大美野田園都市及びそれ以降の彼の都市計画・住宅建 築の特徵を明らかにし，またそれらを戦前の郊外住宅開発の系譜に 位置付けることを目的とする。

\section{2. 下村喜三郎の履歴}

下村喜三郎 ${ }^{2}$ は表一 1 に示すように, 明治31年 2 月27日に大阪市 浪速区の鈴木家で生まれ，大正13年下村家に婿養子に入った。彼は 大阪府立今宮中学校を経て, 大正 5 年 4 月東京高等商船学校に入る が半年で退学し, 翌年東京美術学校図案科第二部（建築科）に入学 した。卒業制作の子供の会館図一 1 は，当時の近代建築運動の影響 を感じさせる作風である。

下村は, 大正11年 3 月 24 日東京美術学校を卒業した後, 早稲田大 学理工学部建築学科で恥講生として在籍するが 2 ヶ 月で中途退学す る。同年彼は，東京米国建築合資会社に就職するがこれも 2 ヶ で 退職した。しばらくして, 株式会社大林組東京支店に入社し, 東京 歌舞伎座（岡田信一郎設計）の工事に携わっている。 大正12年 9 月 1 日東京神田で関東大震災に遭い, 堺市高師浜に
引っ越すが, 火災に遭い, 阪急沿線牧落百楽荘に移り住む。この時 期, 下村は関西土地侏社長竹原友三郎に建築技師として郊外住宅地

$$
\text { 表一 } 1 \text { 下村喜三郎の履歴 }
$$

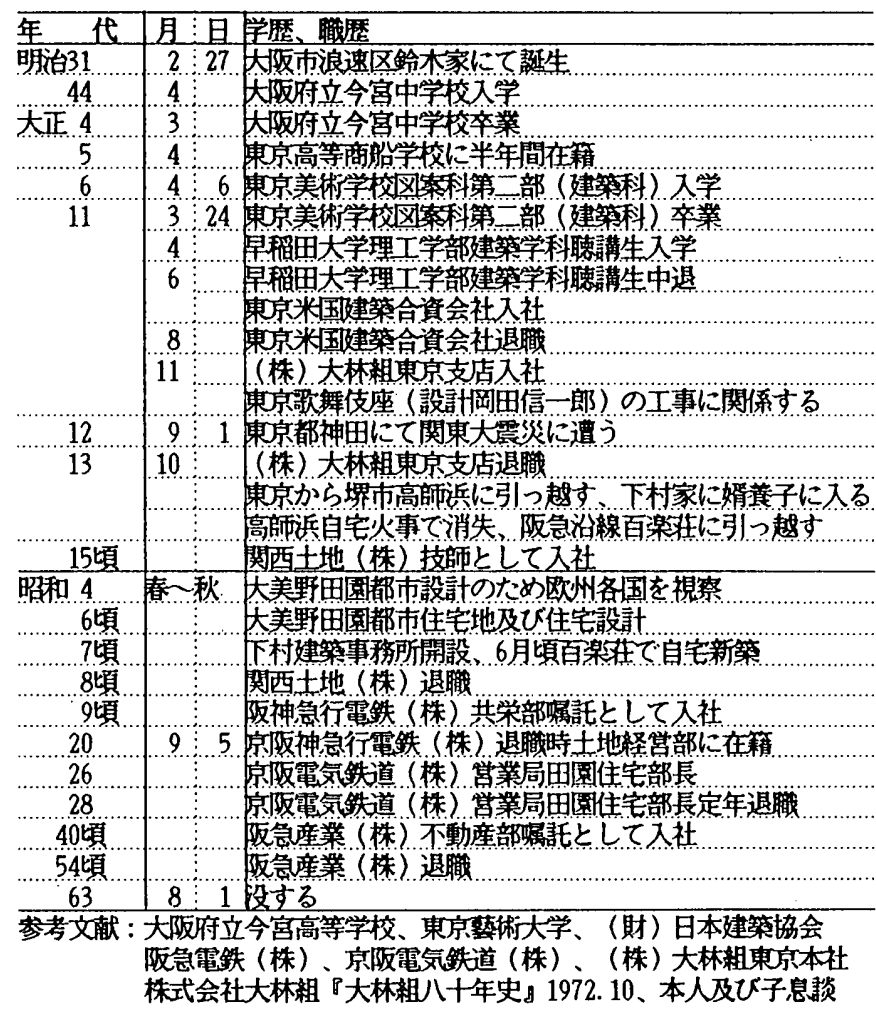

\footnotetext{
本論文は1986，1988年に日本建筑学会大会学術满演梗概集に発表したものをもとに加筀，修正を加えている。

* 大阪市立工芸高等学校 教諭 $\cdot$ 工修

** 大阪工業大学工学部建築学科 教授 $\cdot$ 博士 (工学)

Teacher., Osaka Municipal Arts and Craft High School, M. Eng.

Prof., Dept. of Architecture, faculty of Eng., Osaka Institute of Technology, Dr. Eng.
} 


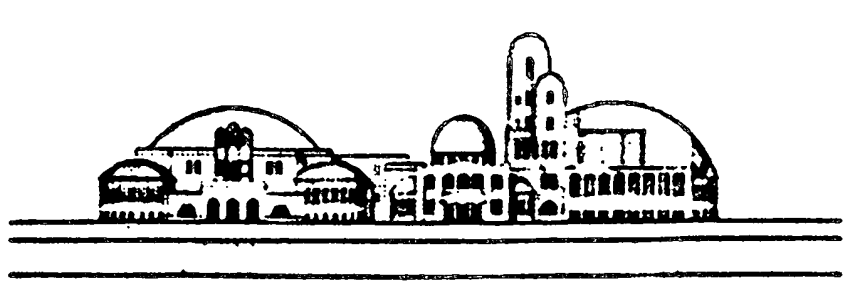

図一 1 東京美術学校図案科（建築科）卒業制作「子供の会館」

建設に関わる仕事を行うために招聘され同社に入社している。入社 後 4 〜 年して, 社長の命により田園都市を視察するために, 彼は 欧洲各国を歴訪している ${ }^{3)}$ 。その目的は大阪南部南海鉄道(侏沿線に 田園都市を設計することであった。昭和 6 年頃大美野田園都市を設 計し, 大美野での住宅地経営が軌道に乗った頃, 下村建築事務所4)を 開設している。

昭和 8 年頃阪神急行電鉄株式会社の求めに応じて，彼は関西土地 を退社し，同社共栄部の嘱託 ${ }^{5)}$ となる。仕事内容は主に宅地開発や住 宅地経営の指導であった。約 20 年間勤めた後，同 20 年 9 月 5 日に退 職した。退職時は組織替えした土地経営部に所属していた。

下村は同26年京阪電気鉄道株式会社営業局田園住宅部長として招 かれ 2 年程勤めて定年（55才）で退職する。同40年頃，彼は京阪神 急行電鉄(侏)の関連会社阪急産業(侏6)に招かれ不動産部嘱託として同 54年頃まで主に宅地開発に力を注いだ。退職後は，兵庫県西宮市塩 瀬町生瀬で生け花の師匠をする米子夫人と過ごし昭和63年 8 月 1 日 没する。

\section{3. 関西土地株式会社時代}

\section{1 関西土地株式会社の概要}

関西土地儌は，その前身である香里園土地建物侏（大正 8 年12月 創立 社長 國枝 䔆 資本金300万问) の事業を竹原友三郎（竹原 商店二代目店主一株の仲買人）が受け継ぎ社長となって社名を帝国 信託(㑣と改め，本格的に不動産事業にのりだした。帝国信託は多く の土地会社を 2 度に瓦り合併吸収し，大正12年10月社名を関西土地 懒と改称した。

この時期から，関西土地の本格的な宅地開発がはじまる。下村喜 三郎が入社したのはその時期である7。関西土地は郊外住宅地とし ては丸山荘園，高師浜，大美野などを開発し，市内にあっては森小 路，西平野，今津で土地区画整理事業に参画して中心的立場で宅地 開発を推進するなど鉄道沿線や市内で手広く住宅地経営を行ってい る。

とりわけ，関西土地は当時注目されていた田園都市を南海沿線北 野田駅西方の地において社運を賭けた事業として開発している。し たがって，同社は表一 2 に示すように(財)日本建築協会の創立十五年 の記念事業に䅡極的に参画した。また，協会が主催して昭和 7 年大 美野田園都市住宅設計図案㲘賞募集や同社，協会，南海鉄道(侏)の共 催によって大美野田園都市住宅博覧会8)を行っている。

関西土地は同12年 6 月新な事業展開を図るために関西不動産侏と 改称，不動建築侏，城南土地(侏)，旭土地興業(儗を姉妹会社として事 業の拡大をはかった。その後の展開は，芳しくなく合併吸収分離を 繰り返し同15年 8 月 3 日不動建築9)となっている。その際, 関西土地 時代所有していた土地建物の帰属は不明である。
表一2 関西土地侏による住宅照出設計，博覧会，展覽会などの一覧

\begin{tabular}{|c|c|c|c|c|c|}
\hline$\overline{\text { 年代 }}$ & 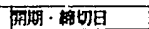 & 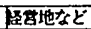 & 鸟イトル名 & 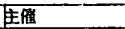 & In \\
\hline 酸和 & 11月8日〜末日 & 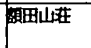 & 家族本位賏就住宅殿完会 & 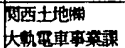 & \\
\hline & 月15日正午 & 大孳影 & 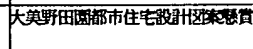 & 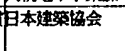 & 日本建筑協会教立消15周年 \\
\hline & $10 月 10$ 1 $11 月 25$ & 大美基 & 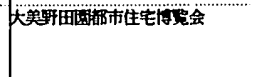 & 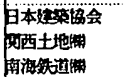 & 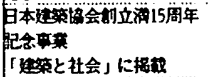 \\
\hline & bi月i日 13日 & 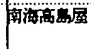 & 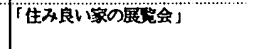 & 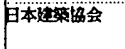 & 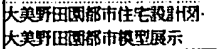 \\
\hline & 3月10日一五末日 & 大美里 & 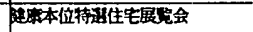 & 阿土地䀳 & 主宅建穼の宜层 \\
\hline & 月 & 大美野 & 放部住宅展 & 可西土地眮 & 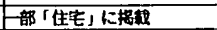 \\
\hline 10 & 朋15日一 5月末日 & 大粕影 & 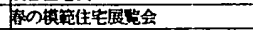 & 的西土地杽 & 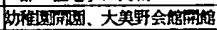 \\
\hline 11 & 阴中 & 大童野 & 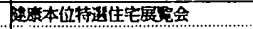 & 票土地相 & 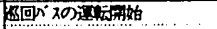 \\
\hline & $10 \cdot 11 \%$ & 大發野 & 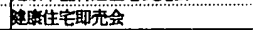 & 阅西土地闌 & \\
\hline 12 & $\begin{array}{l}\text { 月10日-5月末日 } \\
\text { 月 } 10 \text { 日一 } 10 \text { 月 } 10 \text { 日 }\end{array}$ & 庆奥福 & 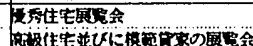 & 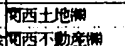 & 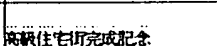 \\
\hline & 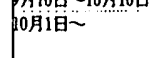 & 大这舟 & 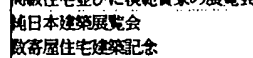 & 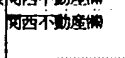 & 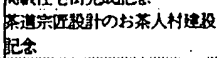 \\
\hline & $10 月$ & 㫦小路 & 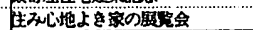 & 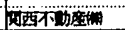 & \\
\hline 13 & B月1日 & 和小格 & 用用住宅展党会 & 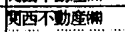 & \\
\hline & $\beta 3150 \sim$ & 大英野 & 特生它晨会 & 网西不野相 & \\
\hline & ค月i日 - 38 & 大粕野 & 完人村完成郡各孛出 & 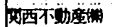 & 一部现草 \\
\hline
\end{tabular}

さらに，戦後不動共栄侏になり昭和37年 7 月 12 日に解散してい $3^{10 \%}$ 。

\section{2 下村喜三郎と関西土地(秼について}

建築技師として入社した下村喜三郎は, 大正15年 1 月の写真図 -2では，主だった社貝の中心に位賀しそれだけ期待される人物で あった。設計部のメンバーと思われる昭和 7 年 3 月の写真図一 3 が あり，下村は設計部のチーフとして仕事をし角野孝，三戸谷和久な どが助手を勤めていた ${ }^{11) 。 ~}$

設計部の動きを知る手がかりに住宅改良会発行の『住宅』による 表一 3 がある。角野，三戸谷は『住宅』12)に設計部の一員として登場 し, 角野は大美野田園都市でライト風の家中野邸を設計し，三戸谷 も同じく大美野で新日本の小住宅原氏邸を設計，住宅改良会主催の 住宅式百号記念「改良住宅」照賞設計に 1 等で入選している。当然, 下村も関西土地が大正末から宅地開発していた牧落百楽荘に昭和 7 年頃設計した自邸図一 4 を「睤のない小住宅下村邸」13)として発表し たり，「週末住宅と生活の簡易化」と題して執筆している。

\section{3 田園都市設計のために欧州各国を視察}

下村喜三郎は, 関西土地発行の関西土地時報14)などに住宅, 田園都 市，大美野田園都市について執筆をしている表一4。彼は欧州各国 を視察した内容を関西土地時報に「住宅のすなっぷ」表一 5 と題し て18回にわたって開発者や住宅地の状況などを詳しく紹介した。そ の感想には，ろんどん一べりんがむを観て「一中略一あわれな日本 の一住宅経営関係の技術者である私は, 長大息と共に, やわらかな RECREATION GRDの芝生に，身を投げ出して羡望と共に，のす

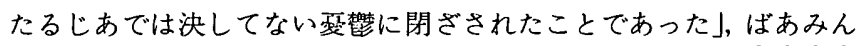
がむ一ぼおんびるにおいて「一中略一従来の工場地の概念から全く かけ離れた，BOURNVILLE INDUSTRIAL VILLAGEの印象は， 永久に私から失われないであろう」などの内容からみて下村は英国 の郊外住宅地づくりの賛美を繰り返すとともにわが国での実現に夢 を描いていたようである( . . 印は原文のまま)。

㷌国後大美野田園都市を設計した下村は, 住宅地案内のパンフ レットに,「田園都市とは レッチワアスと ウエルウインとの 田 


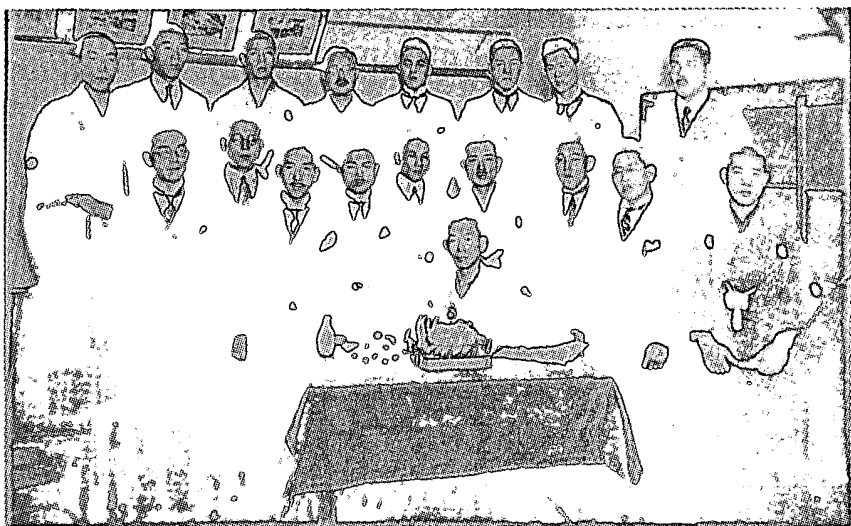

图一2 関西土地秝の主だった社員（大正15年 1 月撮影）最前列が社長その後 列左から 2 番目が下村

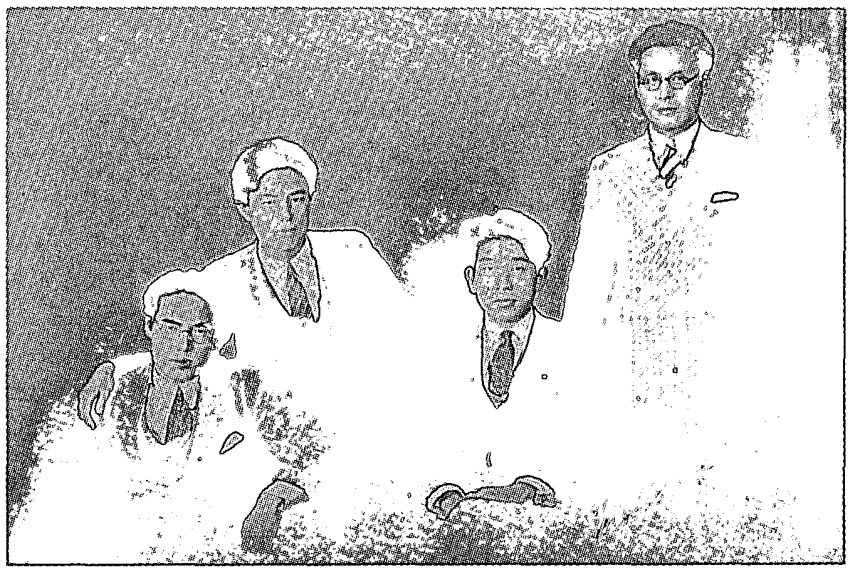

图一3関西土地侏設計部の人達 (昭和 7 年 3 月影影) 右側で立っているのが 下村

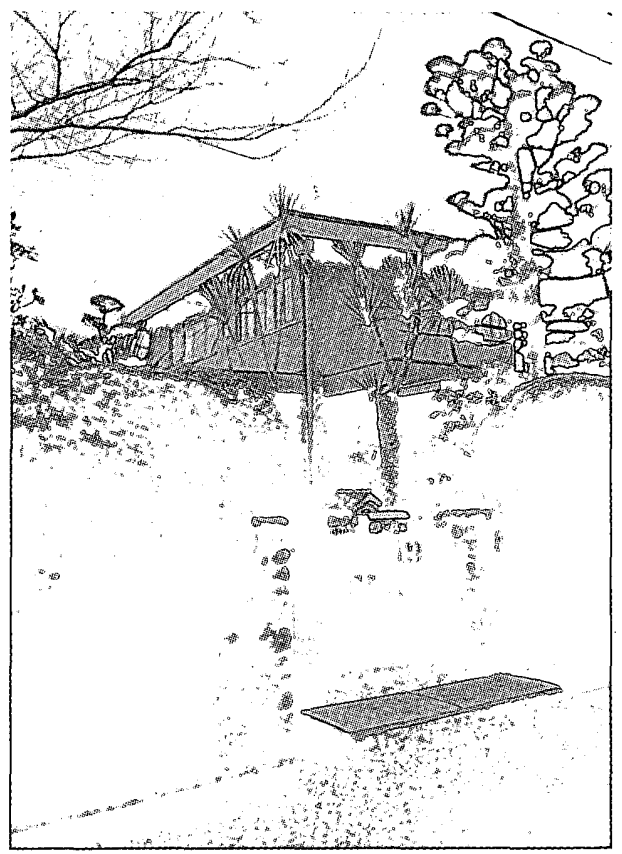

目一４阪急沿線百楽荘に建つ元自邸 (昭和 7 年頃 下村喜三郎設計 1996.2.21撮影)
表一3 住宅改良会発行「住宅』に掲载された関西土地俐の設計·施工による 住宅等の一覧

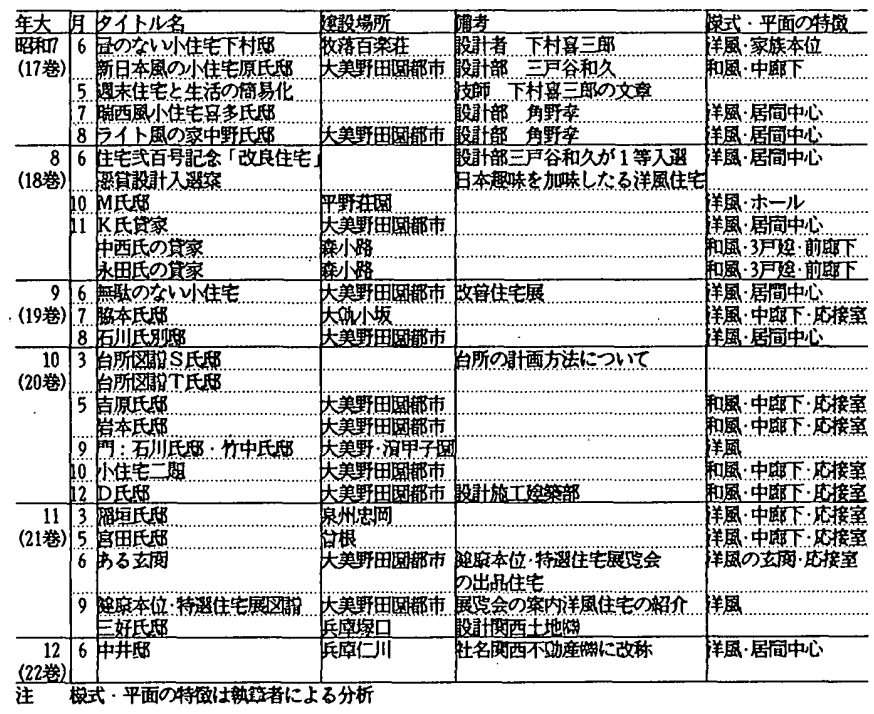

表一 4 関西土地時代の執筆，作品等の一覧

\begin{tabular}{|c|c|c|c|}
\hline \multirow{3}{*}{$\begin{array}{l}\text { 年代 } \\
\text { 昭和 } 3\end{array}$} & 迌旦 & 盖夕イトル等 & 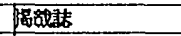 \\
\hline & +9 & 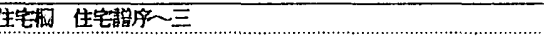 & 閔西土地時赫 \\
\hline & 10 & 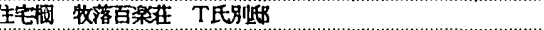 & 阅西土地時報 \\
\hline \multirow[t]{6}{*}{5} & $3-5$ & 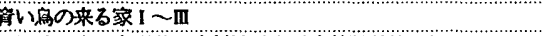 & 问西土地時赤 \\
\hline & 10 & 岳に娒 & 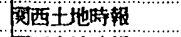 \\
\hline & & 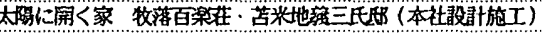 & 咸西土地時報 \\
\hline & & 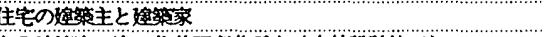 & 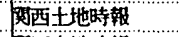 \\
\hline & & 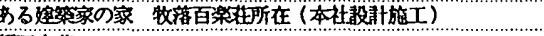 & 閶西土地時熵 \\
\hline & 麗 & 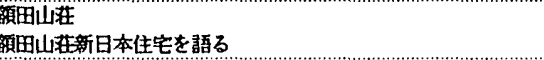 & 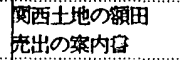 \\
\hline $5 \sim 6$ & & 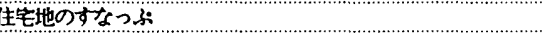 & 阙土地時城 \\
\hline \multirow[t]{4}{*}{6} & & $千 九$ 百三十一年の棟穴住宅 & 雅西土地時乵 \\
\hline & & 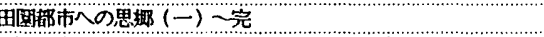 & 悦西土地時報 \\
\hline & 潾 & 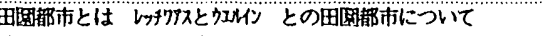 & 阙西土地の大美野 \\
\hline & & 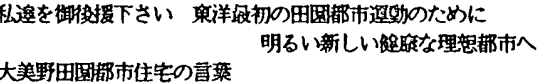 & 热出の踭内白 \\
\hline \multirow[t]{4}{*}{7} & 6 & 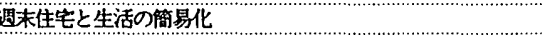 & 住毛 (住宅改食会) \\
\hline & & 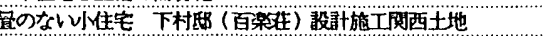 & 䅦土地肪報 \\
\hline & 7 & 厦と住礼 & 暲人フォーラム \\
\hline & & 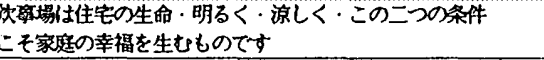 & 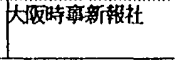 \\
\hline
\end{tabular}

表一 5 関西土地時報「住宅のすなっぷ」による下村喜三郎の歩んだ欧州の田 園都市等の一堅

\begin{tabular}{|c|c|c|c|}
\hline \multicolumn{4}{|c|}{ 回數発行年月 頁 閶西土地時報「住宅のすなっふ」のタイトルと内容 } \\
\hline 1. & 昭和5 & 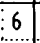 & 1 \$IEDLUAG, BERLIN-BRITZ \\
\hline 2 & & 7 & $x$ \\
\hline 3 & & 8 & \\
\hline 4 & & 9 & 1 OUSSELDORF 市営住宅AM;CHEIN 1920年市建局の設計 \\
\hline 5 & & 11) & 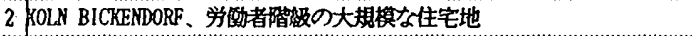 \\
\hline 6 & & 12 & 2 MSTERDAM ZUIDPTUINDORP OOSTZAAN (田圆都市) 他 天作家DE KLERK \\
\hline 7 & & 1 & 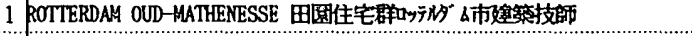 \\
\hline 8 & 招和6 & 2 & 欠 \\
\hline 9 & & 3 & 2 LONDON BELLINGHAM 大佮㔀市 (LONDON COUNTY CONACIL)による \\
\hline 10 & & 4 & 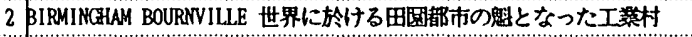 \\
\hline 11 & & 5 & 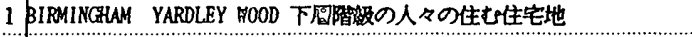 \\
\hline 12 & & 6 & 1. 5 AANCHESTER MITHINGTON MANCHESTER HOUSING CORPORATIONR圣営 \\
\hline 13 & & 7 & 1.5 LIVERPOOL SPRINGFOOD 市O住宅委夏会HOUSING COAMITTEE \\
\hline 14 & & 8 & 1.5pARIS-Pressis-Robinson 田嵲都市 (Cite Jardin) \\
\hline 15 & & $\vdots 9$ & 1.5PARIS- GENEVILLIEPS田圈都市 (Cite Jardin) \\
\hline 16 & & 10 & 1.5 ILAS及USDE DUGYYO田園都市（Cite Jardin) \\
\hline 17 & & i1 & 2はりのところとここ \\
\hline 18 & & 12 & 1.5BORDEAUX-CIALTIERS MODERNES FRUGES \\
\hline
\end{tabular}


園都市について」を書き, 関西土地時報では「田園都市への思郷」 と題して 4 回に瓦って連載, E. ハワードの提唱する田園都市運動の 内容を次のように紹介した。それは「一中略一英吉利の社会改良家, サア，エベネザア，八ワアドは，千九百二年，名著『将来の田園都 市』を世に問ふて，如何すれば，田園都市の生活に於て，都市の生 活と同様の，物質的利便と社会的利益とが得られるであろうかを考 へ, 都市生活と, 田園生活との他に，この両者の長所を結合して， 積極的，活動的である都市生活のすへてて利益を，美しく明るい田 園生活の中にとりいれることの出来る，第三の生活環境の存在し得 ることを主張いたしました。一中略一」のように説明している。そ れらの執筆から下村の考えを読み取ると彼は，英国から誕生した田 園都市運動が欧州各国に広まったように日本においても実現すべき だと考えていたと判断できる。

\section{4 大美野田園都市の設計}

\section{4 .1 大美野田園都市とは}

大美野田園都市は, 昭和 3 年関西土地が大阪府南河内郡野田村と 大草村 (いずれも現堺市)にまたがる40万坪の農地を地主から買収,

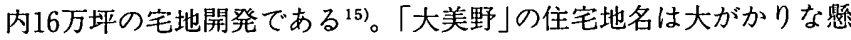
谈募集によって名付けられたもの，大草村と野田村を美しく結ぶと いう意味である16)。

\section{4 .2 街区割について}

下村が大美野田園都市で何をしようとしていたかを知る手がかり として, 本人の話しの他に彼が作成したと考えられる大美野田園都 市第一期売出地々割図図一 5 を揭載する「大美野田園都市 案内書」 と「大美野田園都市 機上より見たる大美野・田園都市の大観」図 - 6 とその裹面の第二期売出地地割図図一 7 がある。彼は, 第一期 の街区割を設計した覚えがあるが北西に広がる第二期は土木部の連

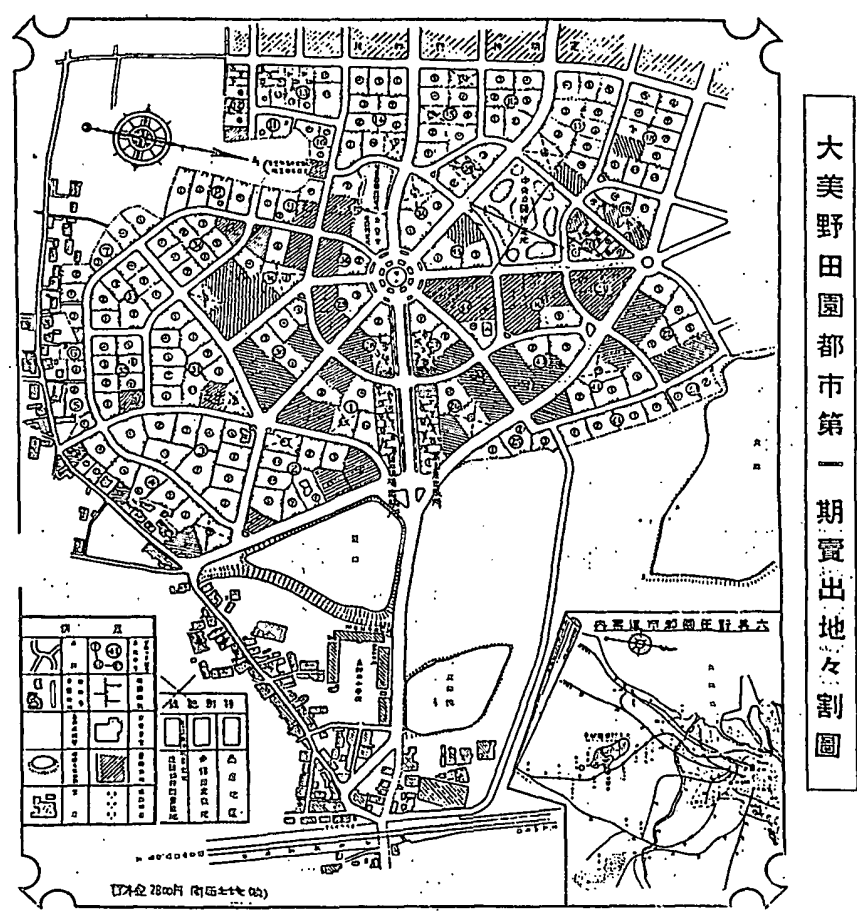

图一 5 「大美野田園都市 案内書」に掲載する大美野田園都市第一期売出 地々割図
中が行っていたようだと語っている。何れにせよ南海鉄道秼沿線北 野田駅から商店街を通って中央広場に至る周辺 5 万坪を設計したこ とは確かである。

その内容は，第一期の案内書によると「荘重広大なる近代ドイツ 式の新道路網，車道と緑樹帯とペーブメントされた軽快な歩道，噴

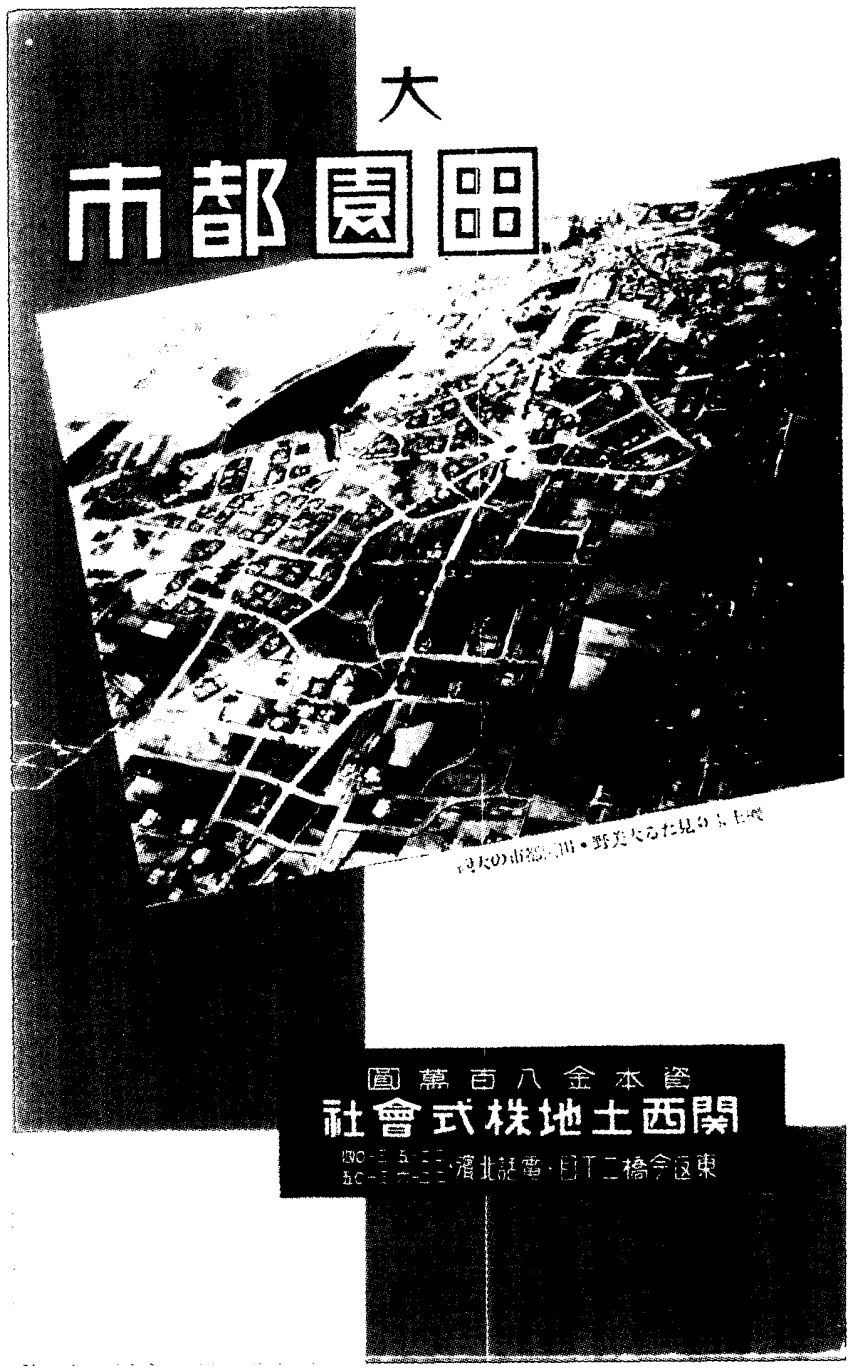

图一６「大美野田園都市機上より見たる大美野・田園都市の大観」

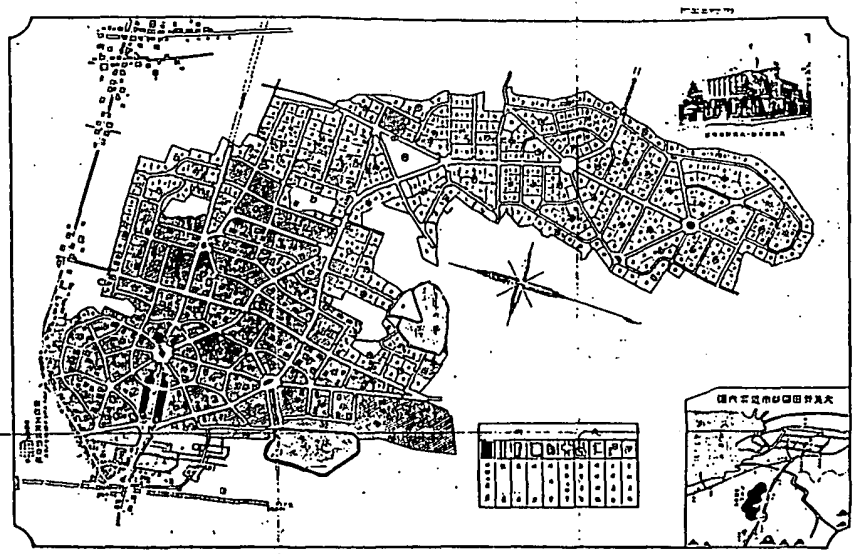

图一7「大美野田園都市機上より見たる大美野・田園都市の大観にに掲載する 大美野田園都市第二期売出地々割図 
水の広場, 公園, 遊園地, 衛生的な暗渠式の下水道, 清澄豊富な上 水道施設, 高島屋出張所, 売店, 小学校, 公会堂…… (原文通り) である。また，第二期を紹介する案内書の施設と計画では「道路計 画は裏面の通り美観と興味と便利の三要素を完備せる近代ドイツ風 の荘重，広大なる道路網を採用し，先づ北野田（大美野）駅より幅 員十米道路を新設して経営地に連絡をとり, 経営地内の幹線一等道 路は幅員十六米に拡張して本地の中心街区たる〈中央広場〉に導き， 此所より幅員十米となり十数町西北へ高野街道に達しドライブウェ イとして利用されています。尚中央広場より六條の放射道路が展開 して, 経営地の何れの地点にも最短距離で達する事が出来ます。是 等の道路幅員は最大十六米 (八間八分) 最狭六米 (三間三分) にし て，自動車の乗入に支障なからしめましたと共に，主要なる道路に は，夫々歩道と緑樹带とを設け，運動に散策に便ずることに致しま した。とさらに詳しく説明している。

下村はデザインした田園都市の街区割を近代ドイツ式 ${ }^{17) と し て い ~}$ るが，中央広場を中心に 6 本の放射道路を設けそれらを同心円状に 連絡する手法は，欧州各国の住宅地のどこから影響を受けたのかは 定かではない。ただ彼の執筆した「住宅のすなっぷ 其の九 ろん どん一べりんがむ」では珍しく住宅地の街路に触れ「一中略一この 広場をちゅうしんとして，南北に貫く約十間巾の KING ALFRED AVENUEを始めとして六つの放射路線が，ESTATEの各部分に 通じている一中略一」と説明している。ロータリ一から発する $6 つ$ の放射路線は，ドイツというよりむしろ英国の影響を受けていたの ではと考之られる。この下村の放射街区の発想が大美野の第二期の 街区デザインや土地区画整理であるが森小路の街区構成にも影響を 与えていた ${ }^{18)}$ 。

3.4 .3 住宅地について

下村の欧州視察の成果と推察される「大美野田園都市土地使用上 に関する当社の希望と制限」は次の四項目である。

一，一切の製造工業，其他一般公衆の迷惑となる建物を建築せざる 事,

（隣や近所で機械の音を立てられることは立てる方も気兼ね，立 てられる方も迷惑ですからお互いにこんなことは止め度いと思 います)

二．建築物も建坪は御買受宅地の五割以下にして一区劃壹戸たる 事，但商店地区其他特別の場合を除く，

(これは美観の點からは勿論皆様の保安衛生の上からも是非御 実行を願ひます)

三. 宅地の道路側には道路境界線より二尺以上後退して生垣，門を 設け門灯を點火する事,

（お互いが極く気楽な，のどかな気持ちで此土地に住むのに，見 にくい板塀や殺風景なコンクリートの塀などは全く気分を悪く さ川れます)

四．土地御買受後各自に於て御建築の場合は豫め設計図書を弊社に 御提示願ひ承認を得られ度き事,

（此條項は本土地の統制上必要なばかりでなく, 全く弊社が皆様 の御住宅に对し強い関心を持つの稌り一點でも気分を害される ことのなき様御注意申し上げ度いからであります)
各項目に続いて（）書きは原文のままである。これは下村の郊 外住宅地開発に対寸る考之方を示したものであり，評価できる。

\section{5 住宅の設計}

下村は昭和 3 年頃から住宅に関して洋風か和風かについて関西土 地時報に執筆している。同 6 年「一千九百三十一年の日本住宅」で は「一中略一立式の生活形式による住宅形式が，日本人にも何の不 満もなく適合される日，日本住宅もまた，国際建築として，立派に 世界の檜舞台に上るであらう。その一千九百三十一年を，私は愉快 な予感をもって迎えるであろう。」と述べている。彼の設計による大 美野での住宅は明かではないが，関西土地発行の絵はがきには洋風 住宅図一 8 と和風住宅があり，彼の意図した住宅が建てられていた ことは確かである。

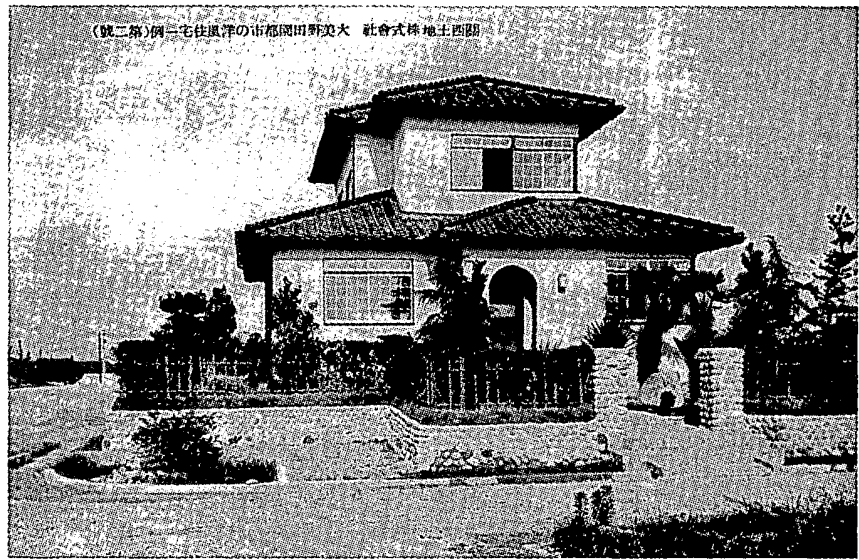

図一8 開発当時の大美野田園都市の洋風住宅一例（第二号）宣伝用の 葉書より

\section{4. 阪神急行電鉄株式会社時代}

\section{1 共栄部嘱託（退職時：土地経営部嘱託）として}

下村が阪神急行電鉄㑣)の求めに応じたのは，彼の執筆「田園都市 とは」19)に「住宅や，住宅敷地は，投機の対照であってはならないの であります一中略一」と述べており土地会社の投機的な業務よりは， 電鉄会社の方がより奉仕的，社会的であるという判断によるものと 推察される。

彼は阪神急行電鉄においても表一 6 や表一 7 に示すように社報や 電気経済時論等に住宅地経営について執筆したり，社員向けに講演 を行っている。いわば，彼は嘱託という自由な身分でありながらも， 会社にあっては宅地開発や住宅地経営のノウハウを指導する立場で あった。

彼が執筆した電気経済時論「顧客層から見た都市近郊電鉄会社住 宅地経営の焦点」(昭和10年11月15日)加住宅地経営の考え方をみ

$$
\text { 表一 } 6 \text { 阪神急行電鉄(㑣)時代の執筆等の一覧 }
$$

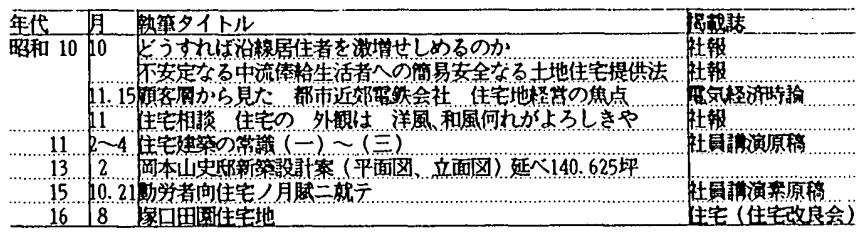


表一7 阪神急行電鉄怢時代の執筆による下村の住宅地経営の考え方

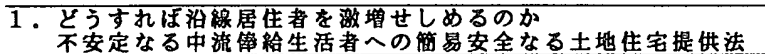

1. 粠言

-当社住宅地経觉の目的は治線間発に在り

- 士地住宅の年月䀡提供法

。土地住宅年月瞅股芫方法の矛盾

- 邚外地における貫住宅

・部外居住者の大多数は中流粭生活者

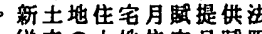

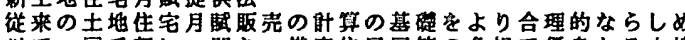

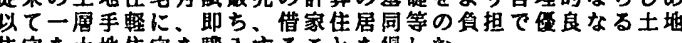

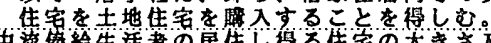

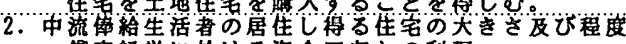

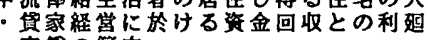

・家異の算定

。聯給生活者の支出し得る珄居制

・叹入年激と住宅の大きさ及ひ程度

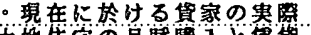

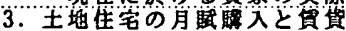

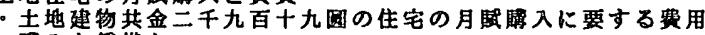

- 熶入界借加

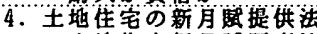

-土地住宅新月眼貶范济

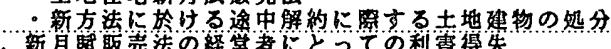

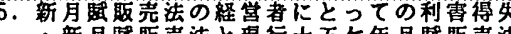

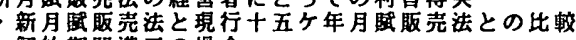

- 解約期間储了の掦合

途中解約の堨合

6. 枯钼

政

・新月明肘売法要約

- 1 月

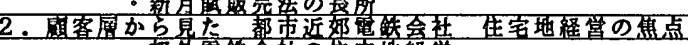

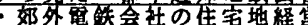

。住安地経営の襍点

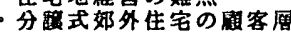

道策上の地位别有壆者

。中饬嗦給生活者住宅

3. 住宅建策の常:

1. 序

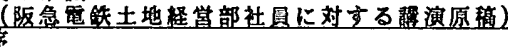

・传宅は建策主自身の手て建てられた

-日本の民家

住宅は誰にも建てられる

・住宅の進化

住宅建努は一般建策界を指導する

- 焦家建籍の常筑

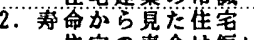

・住宅の寿命は短い

- 伸ひゆく住宅

一室售宅

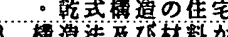

造法及ひ材料から見た性

-木通住宅

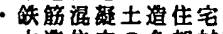

木道住宅の各部材料

4. 能能睍た住宅

住宅の棬能

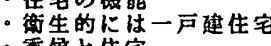

- 秉候と焦富

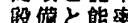

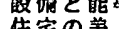

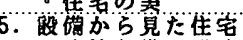

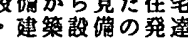

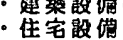

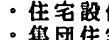

。集团售富の共同即们

住家即橧は世界共通

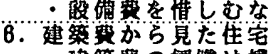

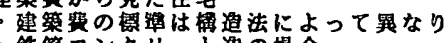

触筋コンクリート遗の揭合

・乾式樰造の星合

杢道の揭合

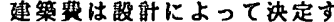

工费と工事期間

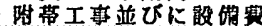

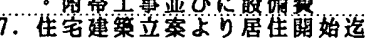

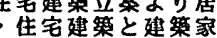

。建室建筑と建努家

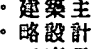

工各毁部

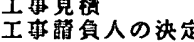

实留渭算式施工

工事の監留

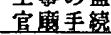

ると,郊外電鉄会社の住宅地経営の目的を次の二点に分析している。

その一は, 住宅地経営事業から直接に利潤を得やうとすること，
即ち，電鉄会社の副業として之を行ふことであり，

その二は, 住宅地経営事業は奉仕的に之を行ひ，以て沿線開発の 速度を急速にし，運輸，電気供給等の本業の躍進を期すること，即 ち，本業の側面工作として之を行ふことである。（その一，二は原文 の通り)

以上の考えに基づいて，彼は「一中略一土地を売って儲けやうと することは，純然たる土地経営会社のやることであって，郊外電鉄 会社といふ特殊の立場にあるものとしては，少なくとも沿線に於け る土地経営の上では，その優先権を放棄したものと言ってもいいと 思子一中略一」と郊外電鉄会社の住宅地経営上の立場を明らかにし, 顧客層は「一中略一資産家階級の有力な顧客を歓迎せずとも住宅実 需家である小市民階級の顧客層を十分吸収し得るを以て沿線の人口 は著しく増加し，本業の隆興を期し得る結果となると同時に，又， 重大な社会問題である住宅問題解決の一端として，社会に奇与する ことを得るわけである。一中略一」として捉えその社会性を説いて いる。

また, 彼は分譲式郊外住宅地の顧客層は中流俸給生活者とし， 「一中略一ここに言子, 標準的な中流俸給生活者住宅とは, 年収千五 百円の俸給生活者が獲得し維持する負担に堪え得る住宅を言ふので ある。」想定し，経営方針では「即ち，土地，建物共売買する現在 の分譲式住宅地経営法に於ては, 収入年額千五百円の標準的中流俸 給生活者の，十五ヶ年賦にて購入し得る住宅は，建築費延坪当り金 一百円，土地代金一坪当り金十二円として，建物延坪数十五坪の大 きさであることを知るのである一中略一」と試算を示しながら住宅 地経営の実務についても精密な分析が見られる。

下村は，建築技師でありながらなおかつ住宅地経営の感覚をもっ た人物であると評価できる。阪神急行電鉄(侏)はそのことに着眼した のではないかと考える。

\section{2 住宅地の設計}

\section{2 .1 塚口田園住宅地}

下村は，昭和16年 8 月住宅改良会発行の『住宅』に塚口田園住宅 地図一 9 と俸給生活者の住宅図一10を発表した。彼は，この二千数 百坪の小規模の住宅地の設計にあたっても「一中略一ここに揚げた 塚口田園住宅地は土地経営者の営利的商品である。尤も阪神急行電 鉄会社の経営になるが故に，土地経営専業の者それのやうに，営利 一本槍でないと勿論であるが, それにしても特定の需要者のために, 社会施設として建設されたものではなく,所謂建売住宅なるが故に, 萬人向きの商品としての計画を要求せられることは当然である。 一中略一」と考之，ここでも欧州で視察した田園都市の実現にはは ど遠い住宅地経営に深い焦燥感にとらわれていたと考えられる。

しかし, 彼は小規模な住宅地であっても次の事項について配虑し ている。

「各宅地の一部を生垣の外において芝生とし, 道路添の緑地として の効果をねらったこと，二階建を北に平家を南に配置して日照をよ くしたこと, 曲線道路による配置の美観を重要視したこと，小面積 の宅地内で, 便所や他人地境界線から井戸迄の距離の制限や, 物千 場に関する考慮等に相當の苦心が必要であったこと等は設計者とし 


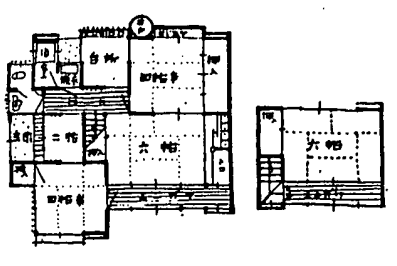

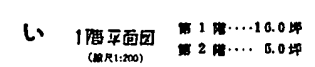

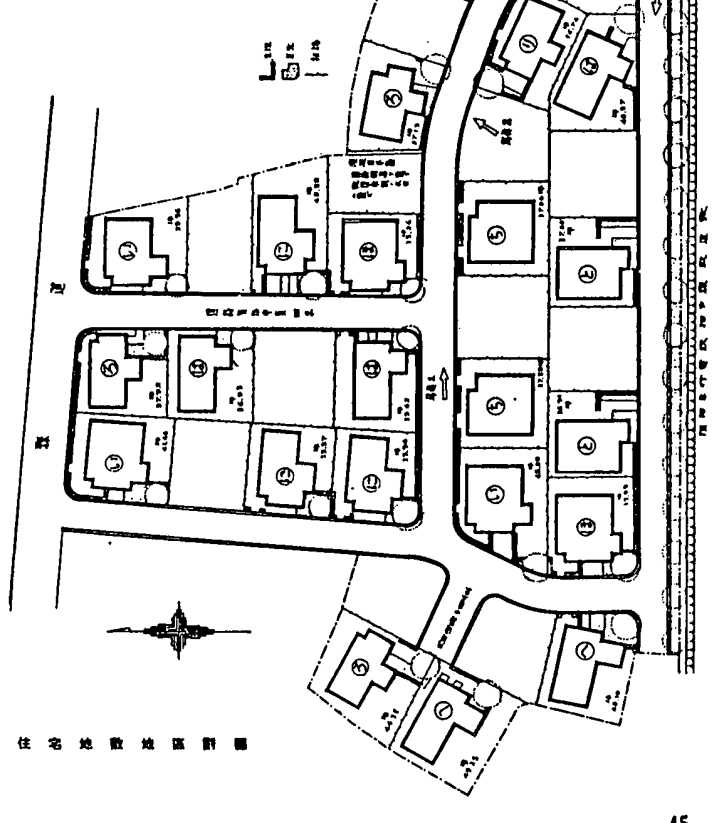

図一9 塚口田園住宅地の設計

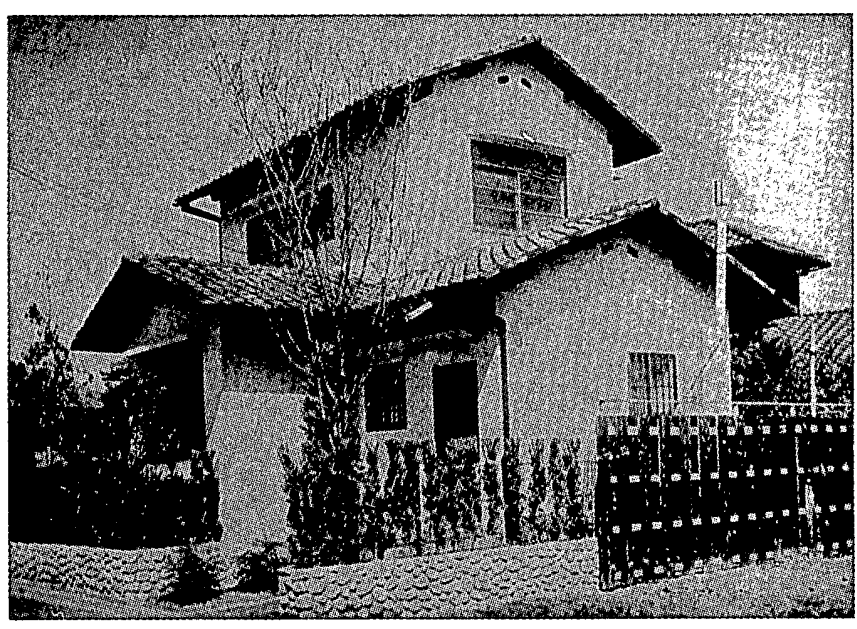

図-10 塚口田園住宅地ろ号住宅

ての多少のみそである。一中略一」

下村は，外遊で感じたことを一部再現しようと試みたが，この執 筆の最後に「一中略一欧州各都市の庶民住宅施設等とは，もとより 比較にも何にもならない, 一中略一どうにか,一つの形にまで漕ぎ つけた庶民住宅地の抗議である。と結んでいる。

\section{2 .2 東豊中住宅地}

下村は，阪神急行電鉄が昭和 7 年頃から宅地開発を始めていた東

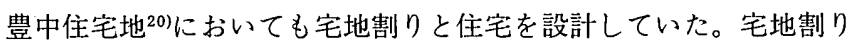

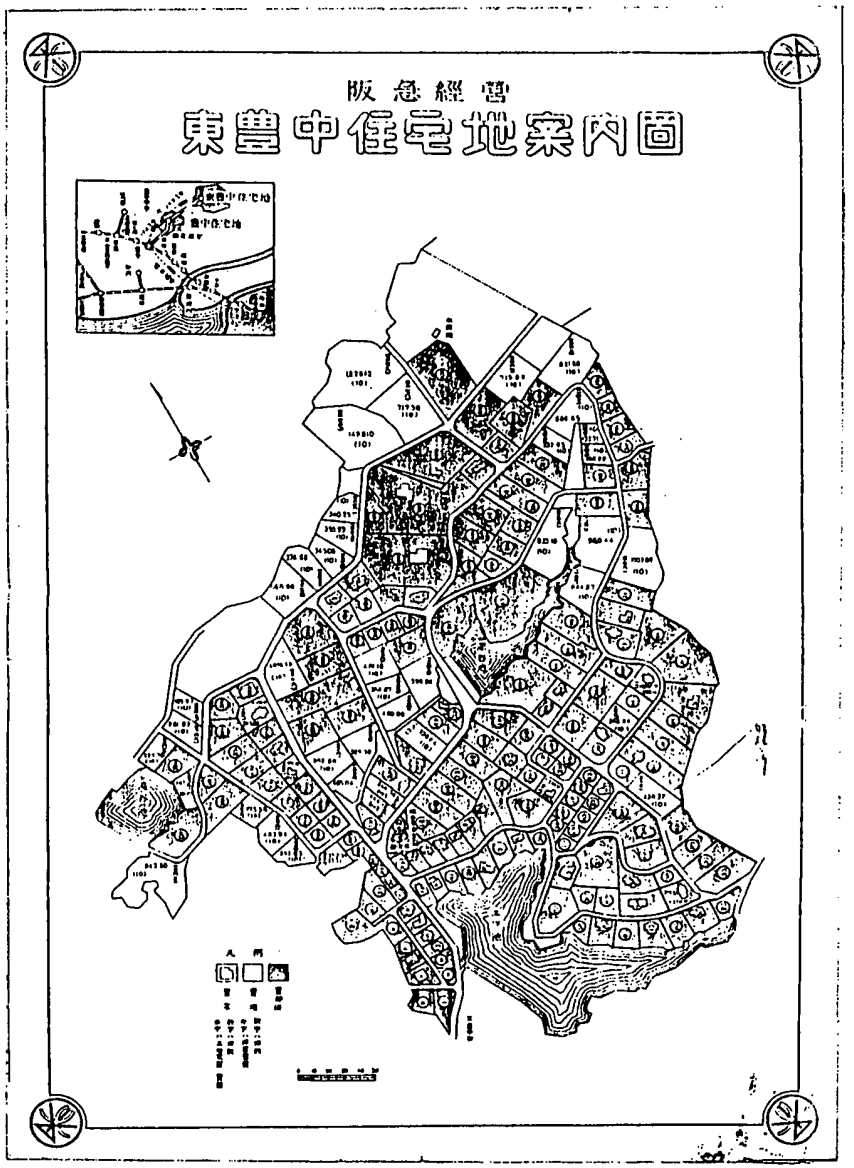

图-11 阪急経営 東豊中住宅地案内図

の手法は, 阪急経営東豊中住宅地案内図一11からみると道路曲線と 宅地との関係による美観の重視, 各宅地の一部を生垣の外において 芝生とし, 道路沿いの緑地としての効果などを採用していることで ある。これらは塚口田園住宅地とかなり共通するところがみられる。 また, 住宅に関しては下村の所蔵図面からみて洋風, 和風, 平家建, 二階建と幅広く設計している。彼は, この 2 箇所の住宅地の他にも 京阪神急行電鉄の経営地田園住宅地などで, 宅地開発や住宅設計に 携わり彼の手腕をおおいに発揮したようである。昭和 20 年秋, 京阪 神急行電鉄を退職した。

\section{3 住宅の設計}

下村は日本の将来の住宅に関して昭和10年11月社報「住宅相談」 の問で「住宅の外観は洋風，和風何れがよりしきや」では「私はこ の問題に対しては, 結局日本の住宅は, 日本のものでなければなら なぬ。従来の伝統的な和風住宅を一歩も出ないものでは, 実際今日 の用途には適しないが, さりとて, 模倣的な洋風住宅も日本には適 しない。こ々に，新しい真に日本的な住宅の新梯式が出なければな らない時になつているのだと申したい。それが出るべくして未だ出 ないのは建築家の努力が足りないと同時に，また建築主に於ても， 心ある建築家に，充分，腕を振ふ機会を與へられることの少ない結 果である。一中略一」と考えている。彼は阪神急行電鉄では経営地 で多くの住宅の設計を行った。東豊中住宅地では別荘向き洋風二階 建 (347号) 図一12を彼の自邸とも共通するモダニズムのデザインで 設計している。また，彼のスケッチブックや写真集には，それらと 


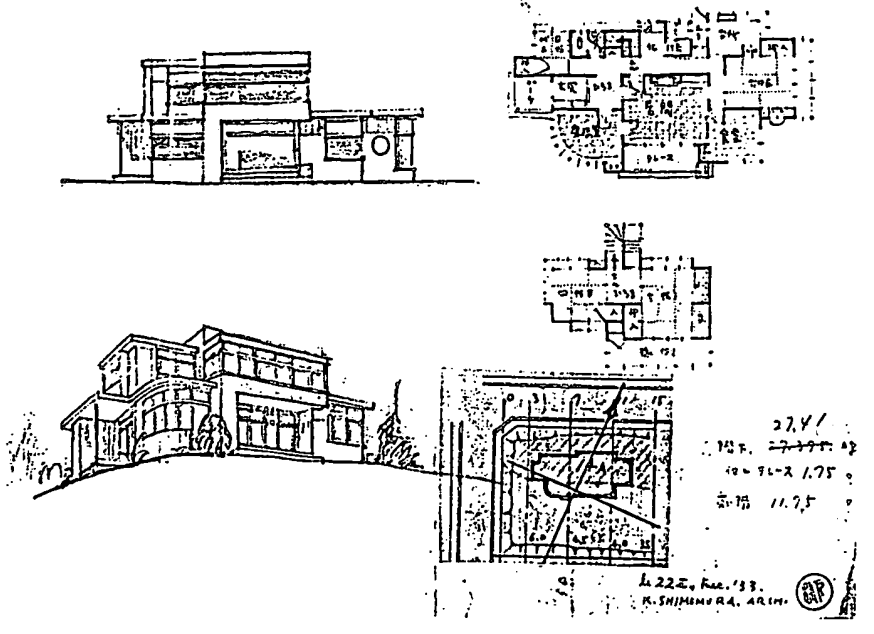

図一12＼cjkstart東豊中住宅地３47号住宅のエスキス

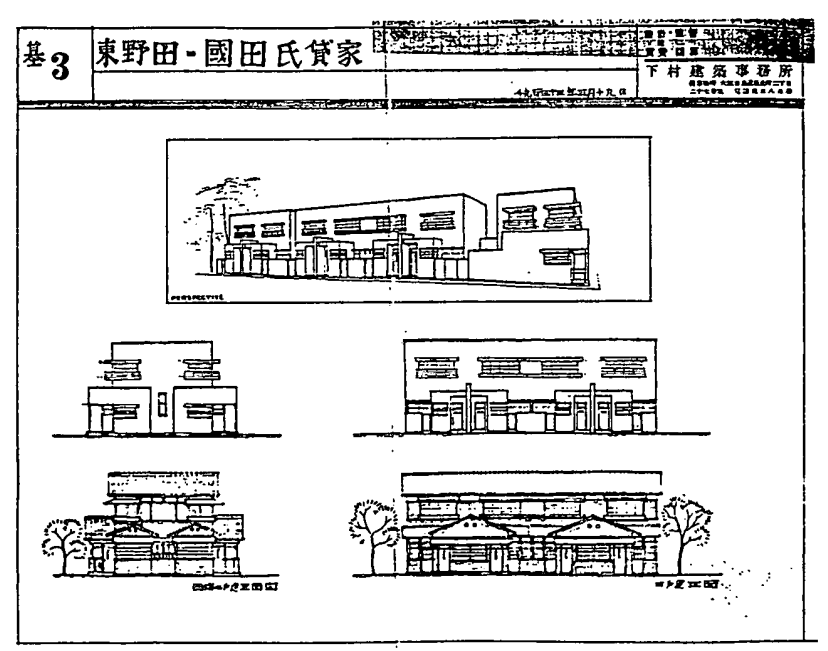

图一13 貸家の設計

は異なる洋風の大邸宅 ${ }^{21)}$ 手かげており，住宅の設計に関しては卓 越したデザインカを持っていたものと評価できる。

\section{5. 下村建築事務所の開設}

大美野田園都市の経営が軌道に乗った頃，下村は建築家として自 由に建築活動を行うために，昭和 7 年頃大阪市浪速区元町に仮建築 事務所を開設し, 昭和 9 年には兵庫県武庫郡精道村に移している22)。 彼の建築事務所では，長屋建の貸家図一13や商店建築などを手がけ ていた。当時建築家が長屋建住宅を設計することは希であったが, 彼が欧州各都市で見聞きしてきたことにより庶民のために設計した ものと考えられる。ただ，彼がいつごろまで建築事務所を開設して いたかは明かではない。

\section{6 . 戦後の活躍}

下村は，戦後しばらくして京阪電気鉄道株式会社に営業局田園住 宅部長として招かれ，定年退職まで勤める。この時期，大美野や塚 口のような目立った活動は見られないが, 指導的な立場で住宅地経 営に関わっていた ${ }^{23)}$ 。

その後，阪神急行電鉄㑣の関連会社阪急産業株式会社の求めに応
じて不動産部嘱託として15年間ほど勤務し，主に宅地開発，住宅地 経営に関与していた24)。

\section{7.まとめ一下村喜三郎の果たした役割と評価}

(1) 下村が関西土地で設計した大美野田園都市は，E，ハワードの田 園都市運動の理念の実現ではないが，駅から噴水までに距離をお いて商店街としていることは,レッチワースやウエルインに共通 する処理である。また, 大阪住宅経営株式会社の千里山住宅地 ${ }^{25)}$ も共通している。大美野のデザインは40万坪全部ではなかったけ れども奔放な街区計画は関西の郊外住宅地開発に強烈なインパク トを与えた。住宅販売に際してパンフレットなどを通じて田園都 市を紹介したり，関西土地時報を発行してヨーロッパの20世紀初 頭の住宅地の実態を紹介するなど啓蒙的な役割を演じたことは評 価してよい。

(2) その後鉄道企業系の住宅地開発に転じて東豊中，塚口などで業 績を残すが大美野のような強烈な内容でなくトーンダウンせざる を得なかった。このことについて彼は「一中略一欧州各都市の庶 民住宅施設等とは，もとより比較にも何にもならない,一中略一ど うにか一つの形にまで漕ぎつけた庶民住宅地の抗議である。」26)と かなり不満であったようである。戦後京阪に転じているがそこで は彼の能力を引き出せるような仕事に巡り会えていない。

(3) 下村は住宅地計画以外に，建売住宅の設計をしている。その住 宅地に適したものをというとであった。それ以外に自邸を含めい くつかの個人住宅を設計している。その作品に建築事務所を主幸 する建築家の片鱗が見られるが，その活動は必ずしも長続きして いるわけでない。戦時体制が強化された時期という時代の背景も あるがなんら他に影響を与えることがないまま引退している。

その中にあって彼は，西欧の住宅地で見た労㗢者階級の住宅に 刺激され庶民のための長屋建住宅を設計し，市民派を貫いたこと は評価してよい。また，当時西欧に展開した近代建築運動にも敏 感に影響を受け卒業制作，自邸，建売住宅などに作品として発表 していたことは，大美野田園都市のデザインとともに評価に值す るものと考える。

(4) 彼は図面の端々にフランス語を用いるほどフランス語が得意で あったという。当時としては洋行帰りのリベラリストであった。 関西土地以降仕事を転々とするが正社員ではなく嘱託として，か なり自由に振る舞いたいということであった。フランスの影響は 彼の市民派を貫いた生き方や，フランスの近代建築運動の影響を 感じさせる住宅建築のデザインに少なからず反映していたものと 考えられる。

(5) 彼の建築の経歴から見てなぜ関西土地社長竹原が自社に招き入 れたのか疑問が残る。関東大震災の被災後関西に戻り高師浜や牧 落百楽荘に居を構えることになるが，いずれも関西土地の開発地 であることと何らかの関係があるかも知れない。この疑問はデべ ロッパーと建築家という構図から考えても早急に明らかにする必 要がある。

\section{謝辞}

本稿作成にあたり下村喜三郎様並びに奥様の米子様にお世話にな ク, 関西土地時報をはじめとする多くの資料を提供して戴きました。 
1988年の春 2 度訪問し, 大美野田園都市などについての考え方を窥 いました。また，履歴に関してはご子息下村按理氏によります。

下村様の東京美術学校での卒業制作閲覧に際しましては, 東京芸 術大学美術学部建築科前野堯教授にお世話になりました。大美野田 園都市売出地割図の便宜を図って戴いた大美野幼稚園，白山家，ま た，下村様の履歴などに関しては株式会社大林組東京本社，阪急電 鉄株式会社, 京阪電気鉄道株式会社, 阪急産業株式会社, 関西土地 株式会社の関係者，大阪府立今宮高等学校，元住宅改良会『住宅』 編集人で新住宅社編集長小林清氏などの皆様にご教示いただきまし た。記して謝意を表します。

\section{脚注}

1）本稿は，「長屋住宅による市街地形成に関する研究 その14 住宅地開発 と長屋建設一関西土地の場合」,『日本建築学会大会学術講演梗概集」pp. 305 306.1986, 「郊外住宅地開発の史的考察 その 1 関西における土地 会社の活躍一関西土地陎の場合」、「日本建築学会大会学術講演梗概集」pp. 357 358.1988, 「郊外住宅地開発の史的考察 その 2 住宅地開発に関 わった人たち一下村喜三郎の場合」、日本建築学会大会学術講演梗概集」 pp.359 360.1988の既発表論文に加筆・修正を加之たものである。

2）下村は, 東京美術学校卒業時は鈴木喜三郎で大正13年頃下村家に婿養子に 入り下村と姓が変わった。下村のご子息下村按理談による。鈴木家及び下 村家はいずれも建築関係に携わっている。

3）住宅改良会：『住宅』第26卷 pp.44４9.1943.8，「一中略一昭和四年の春 から秋にかけて, 第一次欧州大戦後の有名な住宅経営の跡を, 欧州各国に 見学したことがある。一中略一」による。

4）日本建築協会発行会貝名簿による。下村は昭和 7 年から 9 年まで建築事務 所として登録し同18年までは, 勤め先を阪神急行電鉄陎としている,また， 関西土地の関係者が大美野田園都市の開発の頃昭和に入って会員及び普 通賛助員に名を連ねている。

5）下村によると，共栄部部長阿部悌蔵に求められたとしている。阿部は，阪 神急行電鉄株式会社発行『阪神急行電鉄二十五年史了社長，専務，取締役， 監査役一覧1932.10.18に登場している。

6）阪急産業株式会社：『阪急産業株式会社30年史】pp.174～175. 1976.11.3阪 急産業株式会社は, 昭和 21 年 11 月 20 日阪神急行電鉄より分離独立して日興 殖産保社長堀田正行資本金15万で発足する。同24年 2 月 5 日阪急産業侏と 社名を変更する。下村は元阪神急行電鉄に在籍していた社長堀田の招きに より阪急産業で宅地開発を行う (本人談)。

7）関西土地侏の関係者丹羽 良による。

8）日本建築協会：大美野田園都市住宅設計図案照賞募集規程『建築と杜会」 会告 Vol.15.No.7，1932.7, 大美野田園都市住宅博覧会概要「建築と社会」 会告Vol.15.No.9，1932.9による。

9）関西不動産侏の不動産の名前では戦争中では商売が出来ないという理由 から改称している。関西土地の関係者による。

10）野村德七商店調查部『株式年鑑』1909 1924, 大阪屋商店『株式年鑑」 1924 1942, 各社営業報告書, 会社登記簿および関西土地碀の関係者によ る。

11）下村からの説明による。

12）住宅改良会：『住宅』17巻 6 号p. 333,8 号pp.484 485, 18 巻 6 号 pp 325 348による。角野孝は日本建策協会名簿には昭和 4 年から 7 年まで勤 め先関西土地普通賛助員で登録されている。

13）下村は大正13年頃加ら阪急沿線牧落百楽荘で居住し昭和 7 年頃自宅を設 計している。いつまで居住していたかは明かでない。
14）関西土地時報は関西土地㑣の関係者が発行していたようで,いつからいつ まで発行されどの程度配布されていたかの詳細については明かでない。下 村は文章は得意だったとし執筆のほかに装丁のデザインや関西土地時報 を編集していたと語っている。表の関西土地時報はすべて下村からの提供 による。その体裁は彼の記事のみを切り拔きスクラップブックに添付して いるため残念ながら明かではない。

15）大阪府南河内郡登美丘町町史編籊委員会: 『登美丘町史』pp 300 302.1954.4.10, 買収にあたっては地元の小作人の反対があり 3 年間 に及ぶ紛争の後,小作調停法によって面積の半分近くを地主からの買値で 農家に変渡することが約束されたという。

16）大阪朝日新閆「田園都市名称の懸賞当選発表 大美野田園都市」1931.4.8, 『登美丘町史』pp.300 -302と大美野を宣伝する「看板」による。

17）大美野田園都市が案内書や日本建築協会発行雑誌などに公表された時に は近代ドイツ式と紹介されていたが，下村の E．八ワードの田園都市運動 に関連する多数の執筆や「私は他人のものはとらない，デザインにかかる 時誰かが急に外国の理論を採用した」「「視察ではドイツは素通りした」の 聞き取りと,関西土地の社運をかけた住宅地開発であったことから下村の 意志より経営に有利な当時友好国であったドイツを前面に出したのでは との判断による。

18）本人談「住宅地の街路は放射状を良しとしていた」と子息下村按理談によ る。

19）関西土地が大美野を売り出すための案内書で, 下村が昭和 6 年春に執筆し たものである。表一 4 に掲載する。

20）日本建築協会：東豊中住宅設計図案懸賞募集规程『建築と社会」会告 Vol 15.No.9 1932.9より開発年代を判断した。

21）阪神急行電鉄侏岡本駅南側に山中金属婌山中直一邸を昭和13年頃などを 設計している。下村の自䈉のエスキスや写真及び子息談による。

22）前揭 4) による。角野孝を助手としていた（本人談）。

23）下村はこの時期すでに開発されていた香里園住宅地に在住しており,昭和 25年から始まった住宅金融公庫融資の住宅建設に関わっていた(本人談)。

24）阪急産業に下村の自筆の報告書が多数保管されている。それによると下村 は「下関市豊浦住宅地開発工事 工事費概要予算」「長府開発工事設計案 （竹中土木提出）に就いて意見」などに携わっていた。

25）都市研究会の設計による。都市研究会は，大正 6 年10月「都市ノ経営二関 スル諸般ノ事項习研究シ都市ノ改良発達 7 促シ福利 7 增進シ国家ノ進運 ヨ扶翼スル 7 目的卜シ」(都市研究会規則第 1 条)とし, 池田宏らが官僚, 識者を募って組織された機関で，大正 7 年 4 月〜昭和 20 年 $1 \cdot 2$ 月まで機 関誌『都市公論』を発行している。都市研究会については, 財団法人日本 住宅センター：戦前の住宅政策の変遷に関する調查 $(\mathrm{V})$ 一戦前住宅政策 のキーワード50-p.18.1984.11及び財団法人都市計画協会：都市計画パ イオニアの歩1986 p.163.1986.9.9による。千里山住宅地については拙稿 山岡順太郎と大阪住宅経営株式会社,「日本建築学会計画系論文集第486 昂」pp.167 176.1996.8に発表している。

26）4.2.1塚口田園住宅地での再揭である。

\section{図版出典}

(1)東京芸術大学芸術資料館：「蔵品目録 困案・デザイン・建築1991」p.25 1991.3

(2)(3)(8)(11)(213大阪工業大学工学部建築学科寺内研究室

(5)白山家

(6)(7)大美野幼稚園

(9)住宅改良会発行『住宅」26巻 p.45 1941.8

(10住宅改良会発行『住宅』26巻 p.47 1941.8

（1996年 4 月 10 日原稿受理，1996年10月31日採用決定） 